\title{
A STUDY OF THE WASSERMANN REACTION IN ONE HUNDRED INFANTS *
}

\author{
KENNETH D. BLACKFAN, M.D., S. T. NICHOLSON, JR., M.D. \\ BALTIMORE \\ AND
}

T. WISTAR WHITE, M.D.

ST. LOUIS

In an article entitled "The Wassermann Reaction in Children and Infants," Churchill ${ }^{1}$ states that a positive serum reaction was found in thirty-nine of 101 children examined. The cases were taken "mostly at random" from a large hospital for children. There was a family or past history of syphilis, or signs of the disease, together with a positive serum reaction in twenty-nine of these cases. In the ten other cases, the serum reaction was positive without a history of or evidences suggestive of syphilitic infection. The technic used in some of the cases was that recommended by Wassermann, but in the majority the Noguchi modification was employed. Churchill was surprised to find so large a number of positive serum reactions in children apparently free from syphilis, but he wisely suggested that further studies were necessary before valid conclusions as to the incidence of latent hereditary syphilis could be drawn.

\section{AUTHORS' INVESTIGATION}

In this investigation the sera from 101 infants, irrespective of the reason for which they were in the hospital, were tested. The technic employed was that advocated by Wassermann, and in forty-three instances this was supplemented by tests made according to the method of Noguchi. The blood was procured by means of the suction apparatus described by Blackfan. ${ }^{2}$ The collection, from infants, of blood for the Wassermann test has always been attended with difficulty, but by the use of this method a sufficient quantity for both tests was easily obtained. Effort was made to collect all data that might aid in establishing a diagnosis of hereditary syphilis.

Group I.-In this group there were 68 infants from a large foundling hospital. The youngest child was 5 days old, and the oldest was 29 months; 20 were under 6 months, 24 under 12 months, 16 under 24 months and 8 between 24 and 29 months.

* Submitted for publication May, 1913.

1. Churchill, F. S.: Jour. DIs. CHILd., 1912, iii, 363.

2. Blackfan, K. D.: Jour. Dis. Chind., 1912, iv, 33. 
The family history could not be obtained in the majority of cases. The past history and physical examination failed to show in a single instance any evidences of hereditary syphilis. Of the 68 infants tested, 44 were normal and well nourished, 19 were slightly rachitic, 2 had Hirschsprung's disease, 1 had icterus neonatorum, 1 had tetany and 1 had meningitis (probably tuberculous).

Group 11 .-There were 33 infants in this group, from the wards and the out-patient department of the St. Louis Children's Hospital. The youngest child was 2 weeks of age and the oldest was 30 months; 9 were under 6 months, 10 under 12 months, 12 under 24 months and 2 between 24 and 30 months.

The family history was known in all of the cases except one, an illegitimate baby 2 weeks old. It had no bearing on the question at hand in 29. In the remaining 3 cases, there were certain facts suggestive of syphilis. In Case 32, the mother had had one miscarriage and in Case 31 , the mother had had two miscarriages. In Case 33, to which reference will be made later, besides the family history, the past history and physical examination were also suggestive of syphilis. The past history and physical examination of 32 infants in this group presented no evidences of syphilis. The cases studied included children with:

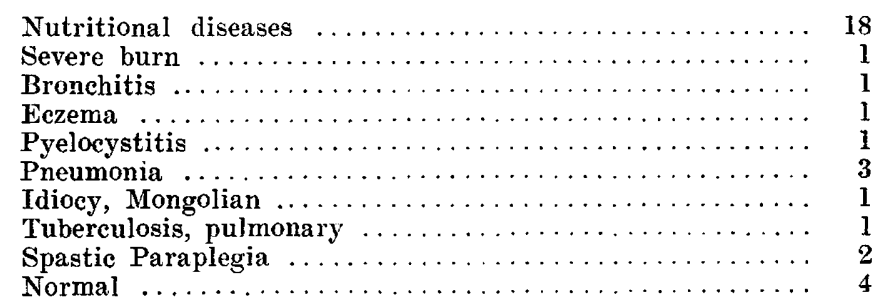

RESULTS OF THE SEROLOGICAL TESTS

Of the 68 infants comprising Group I, the Wassermann test showed no fixation of complement in 66 . These 66 cases do not require further zonsideration inasmuch as the clinical findings failed to show any evidence of syphilis.

Of the remaining 2 infants, there was slight fixation of complement in the serum from one by both the Noguchi and the Wassermann method. This infant (No. 68), 29 months old, was well nourished and there was no reason from the past history or physical examination, to suspect hereditary syphilis. The serum was tested at three different times, and each test gave slight fixation. As there were no clinical evidences of syphilis and as the fixation test at no time was definitely positive, a diagnosis of hereditary syphilis could not be made. The case of the other infant (No. 67) is of interest because no clinical evidences of latent hereditary syphilis were found and the serum caused complete fixation of 
complement. This child, 28 months old, was well developed and well nourished, and had been in the institution since birth. The blood was tested repeatedly, and each time showed complete fixation by both the Noguchi and the Wassermann methods. In view of our present knowledge regarding the specificity of the Wassermann reaction, this establishes the case as one of hereditary syphilis in spite of the lack of confirmatory clinical signs.

Of the 33 infants composing Group II, the Wassermann test showed no fixation of complement in 32 , and complete fixation of complement in 1 .

The infant (No. 33) whose serum showed complete fixation of complement presented signs of syphilis when admitted to the hospital. The mother had had one miscarriage and one still-birth. The baby had had, a few weeks after birth, the snuffles and a desquamation of the skin from the palms of the hands and the soles of the feet. On admission at 6 months of age, the patient, who was undernourished and poorly developed, weighed $71 / 2$ pounds. The spleen was enlarged and the superficial lymphnodes were palpable. This, without question, was a case of hereditary syphilis.

\begin{tabular}{|c|c|c|c|c|}
\hline $\begin{array}{l}\text { ase No. } \\
1 \cdot 66 \\
68 \\
67\end{array}$ & $\begin{array}{l}\text { Family } \\
\text { History } \\
\text { Not known } \\
\text { Negative } \\
\text { Negative }\end{array}$ & $\begin{array}{l}\text { Past } \\
\text { History } \\
\text { Negative } \\
\text { Negative } \\
\text { Negative }\end{array}$ & $\begin{array}{l}\text { Phys. Ex. } \\
\text { Negative } \\
\text { Negative } \\
\text { Negative }\end{array}$ & $\begin{array}{l}\quad \text { Wassermann } \\
\text { No fixation } \\
\text { Partial fixation } \\
\text { Complete fixation }\end{array}$ \\
\hline se No. & $\begin{array}{l}\text { Family } \\
\text { History }\end{array}$ & $\begin{array}{c}\text { GROUP } \\
\text { Past } \\
\text { History }\end{array}$ & 列 & $\mathrm{ra}$ \\
\hline $\begin{array}{r}1-30 \\
31 \\
32 \\
33\end{array}$ & $\begin{array}{l}\text { Negative } \\
2 \text { miscarriages } \\
1 \text { miscarriage } \\
1 \text { miscarriage } \\
1 \text { stillbirth }\end{array}$ & $\begin{array}{l}\text { Negative } \\
\text { Negative } \\
\text { Negative } \\
\text { Snuffles } \\
\text { Desquamation }\end{array}$ & $\begin{array}{l}\text { Negative } \\
\text { Negative } \\
\text { Negative } \\
\text { Palpable } \\
\text { Spleen }\end{array}$ & $\begin{array}{l}\text { No tixation } \\
\text { No fixation } \\
\text { No fixation } \\
\text { Complete fixation }\end{array}$ \\
\hline
\end{tabular}

To recapitulate: In Group I there were 68 children, none of whom gave, on investigation of their family or past history or by physical examination, any evidence of hereditary syphilis. The Wassermann reaction was negative in 66 , doubtful in 1 and positive in 1 . The Noguchi modification was made in 43 of the cases in this group, and verified the results of the Wassermann test; i. e., 41 sera were negative, 1 was doubtful and 1 was positive.

In Group II no clinical evidences of hereditary syphilis were found in 30 infants. In 2 infants the family history was suggestive. In 1 infant, the family and past history and the physical examination were suggestive of syphilis. The Wassermann reaction was negative in 32 of the infants and positive in 1 infant.

These findings are not surprising. They confirm the already established fact that in the majority of patients in which the family and past history and the physical examination are negative, the serum reaction is 
likewise negative. In the same manner a positive reaction in the serum of a patient with signs of the infection, as is shown by Case 33 , is to be expected.

That a child without clinical evidences of syphilis, but whose serum gives a positive Wassermann reaction, may still be syphilitic, is not a new disclosure, for it has long been recognized that hereditary syphilis may remain latent for an undetermined period, and become manifest at a later date. Case 67 is such an instance and emphasizes the great value of the Wassermann test.

The significance of a so-called partial or weak reaction, like that obtained with the serum from Case 68, is not perfectly clear, and judgment as to the nature of the case should be deferred. Observation of the patient and frequent repetitions of the test, must teach the meaning of this type of reaction as an aid to the diagnosis of hereditary syphilis.

Regarding the incidence of latent hereditary syphilis as determined by means of the complement fixation test, larger series of cases must be studied and much more information obtained before definite conclusions can be drawn. The finding by us of one case of latent hereditary syphilis is at variance with Churchill's results, but that this difference is more apparent than real, is evident from an analysis of the cases in his Group V. In this group of his are included children without definite signs of syphilis and without a suggestive history, but with a positive serum reaction. He states that "there is no ground, except a positive serum reaction, for regarding four in this group (Nos. 1, 12, 20 and 31) as cases of syphilis." It seems to us that these should be regarded and classified as cases of latent hereditary syphilis. The positive serum reaction can be explained only on this basis, and a failure to accept this explanation must be taken as an admission of doubt as to the specificity of the complement fixation test, or as an acknowledgment of some error in technic. It would be interesting to know the future history and clinical course of these patients.

The results of this series, in which only two cases gave a positive serum reaction, are strikingly low as compared with the thirty-nine positive cases found by Churchill and consequently do not confirm his observations regarding the frequency of hereditary syphilis among hospital children. Several factors concerning the complement fixation test should be kept in mind as a possible explanation for such a wide variation, viz., the hypersensitiveness of the Noguchi as compared to the Wassermann technic; the personal element present in the interpretation of the reaction and the possibility of error in technic.

These two investigations show conclusively that small series from different sources give widely divergent results, and that further studies of larger series of cases are necessary in order to determine the prevalence of hereditary syphilis among hospital children. 